IRSH 48 (2003), pp. 245-27I DOI: I0.1017/S0020859003001032

(C) 2003 Internationaal Instituut voor Sociale Geschiedenis

\title{
Managing the White-Collar Union: Salaried Staff, Trade-Union Leadership, and the Politics of Organized Labour in Postwar Britain, c.1950-1968*
}

\author{
JOSEPH MELLING
}

Summary: The policies pursued by British trade unions, and especially by the white-collar unions in the second half of the twentieth century, remain the subject of vigorous debate. Many writers have contrasted the egalitarian principles of these institutions and the radical rhetoric of their leaders with the narrow sectional interests which they served in practice. This article offers an alternative approach to such accounts in suggesting that rhetoric and practical behaviour were not contradictory, but complementary, features of union recruitment and bargaining in the period I950-1968. The building of white-collar unions required the officers to think in imaginative ways, deploying a rhetoric and a logic of professional expertise as well as communicating with a diverse and demanding constituency of members. The relationship between the governance of the white-collar union and the politics of the British labour movement was also a subtle and dynamic one in this period of growing state regulation. Clive Jenkins used the resistance to incomes policy as a recruiting sergeant among staff concerned with the erosion of differentials. The most successful white-collar union of the late twentieth century evolved a range of recruiting and bargaining models that were grounded on the hard historical experience of the postwar years, as well as the rhetoric and marketing talents of its charismatic General Secretary.

\section{INTRODUCTION: PERSPECTIVES ON UNION LEADERSHIP}

In I960 Clive Jenkins wrote an article for Trade Union Affairs describing his experiences on a recent trip to the United States. He pointed out that the 3,000 officials in full-time employment with British trade unions

\footnotetext{
* Acknowledgements: The research on which this article is based was supported by the ESRC and the Arts and Humanities Research Board. I am indebted to present and former members of the ASTMS-MSF who assisted in the research, particularly those who were interviewed. Additional thanks are due to the late Clive Jenkins, Gary Morton, and Baroness (Muriel) Turner who also provided documents. The Modern Record Centre, Warwick University provided excellent facilities and support. The research was discussed in depth with Alan Booth, Mark Bufton, Bob Carter, Don Groves, Greta Karpin, David Lyddon, Helen Rogers, Paul Smith, and the editors of this journal.
} 
carried a much heavier workload for less reward than their American counterparts. His itinerary abroad had included a visit to the office of James Hoffa and the American Teamsters' Union, whose business methods Jenkins discussed with some admiration. ${ }^{{ }^{I}}$ In promoting the appeal of collective action for managers as well as technical and supervisory staff, Jenkins cultivated a profile as a "trade-union tycoon" who could be compared with the labour-union bosses feted by American politicians. ${ }^{2}$ This rising star of the Association of Supervisory Staffs and Executive Technicians (ASSET) readily appreciated the appeal of America's business unionism while remaining a fierce critic of the United States foreign policy. Jenkins joined the British Communist Party in the early I950s and married an American communist activist, as well as becoming a prominent role critic of Washington during the Cuban missile crisis. His passionate support for communist Cuba was equalled only by his defence of North Vietnam and bitter criticism of American bombing. ${ }^{3}$

Trade Union Affairs was found and edited by Jenkins and other leftwing union leaders as a forum for serious debate on industrial strategy and public policy. ${ }^{4}$ Much of the success which Jenkins enjoyed by the I960s could be attributed to his skills as a writer, broadcaster, and self-publicist. ${ }^{5}$ As the leader of a union which claimed to embody and express the modernization of the British economy in its transition to a new era of scientific work and computerized communication, Jenkins adapted and altered the rhetoric of class within the labour movement by explicitly claiming to defend the interests of career-minded middle-class executives. ${ }^{6}$ In a period when most trade-union officials regarded the press as their adversaries, Jenkins brought to the ASSET a capacity for communication with the mass media which yielded enormous benefits in membership growth. The result was a truly extraordinary rate of growth which resulted

I. Editorial Board, "We Few, We Happy Few", and C. Jenkins, "Violent Union: The Teamsters of North America", in Trade Union Affairs: A Journal of Study and Criticism, I (1960-1961), pp. 86-94. Clive Jenkins edited the journal.

2. "Clive Jenkins and Co.: Trade-Union Tycoons", Topic, 25 August 1962, pp. I I-I 3.

3. $79 / \mathrm{AS} / 6 / 2 / \mathrm{I}$, for cuttings and pamphlets relating to Cuba including Jenkins's introduction to N. Lewis, Cuba and Fidel. Jenkins became President of the British-Cuban Friendship Society. 4. Jenkins was appointed National Officer at the end of 1958. NEC Minutes, Association of Scientific, Technical and Managerial Staffs (ASTMS) Archive, Modern Record Centre (MRC), AS/79/I/I-6 series [hereafter NEC Minutes], 7-8/I2/I2. Harry Knight resigned as General Secretary in summer 1960. Jenkins succeeded him in December 1960.

5. National Museum of Labour History (NMLH), Manchester, Ian Mikardo Papers, 4/I/7, Victory for Socialism Minutes: Jenkins recorded one of the highest votes of 22 I in December I95 8 for the VS Council. He described himself as ASSET national officer, St Pancras Councillor and "writer".

6. The I 970 adverts designed by David Abbott for ASTMS, "The Board and I have decided we don't like the colour of your eyes", included the statement: "The manager is a key part of British industry". 
in Jenkins's union claiming well over 400,000 members by I 979 and almost 660,000 by the time of his retirement in 1989 .

In the early i960s, ASSET remained a small organization of little more than 20,000 members, a minority of whom paid the union's political levy. Ambitious left-wing leaders of smaller unions often faced the solid hostility of larger general unions at the Trades Union Congress (TUC) and Labour Party conferences, where the moderates often dominated the agenda. Such opposition only sharpened Jenkins's scathing commentary on conservative union leaders who were "always long on expediency, and short on theory" ${ }^{7}$ Jenkins saw that the white-collar unions could not rely on the appeals to historical experience and traditional custom which sustained the manual unions. Under his leadership, the Association of Scientific Technical and Managerial Staffs (ASTMS), the successor to ASSET, provided a regular and highly-respected research report on the British economy. ASTMS attracted professional employees to the ranks of trade unionism by presenting an informed analysis of economic change and industrial regeneration. In promoting analysis and discussion among the trade unions, Jenkins was concerned not only with acquiring expertise to enhance the bargaining capacity of the union, but also with the management of knowledge for strategic effect. In this sense, he was as concerned with the rhetoric form of knowledge and meaning as with the content of information.

Jenkins's command of the media was secured not only by an unquestioned talent for providing memorable headlines. His keen appreciation of the relationship between knowledge and power was also expressed in brutal clashes with his critics. He became an enthusiastic complainer to newspaper editors and to the Press Council, demanding a right of reply and proving a ready litigant who drew a considerable income from successful libel actions against the press. ${ }^{8}$ The hostility of his conservative enemies was only surpassed by the savage attacks on Jenkins

7. MRC, 79/AS/3/3/17, File on membership of ASSET, 1964-1966, shows membership of 24,55 I in I 960 with 3,950 paying the political levy; ADC Minutes, Southport, I964, pp. 17-i 8 ; ADC Minutes, Hastings, I965, p. 33; comments on resolution I6a. Len Powell had served ASSET for eighteen years by 1965. For the earlier, similar, experience of Bryn Roberts of the National Union of Public Employees, see Robert Taylor, The Fifth Estate: Britain's Unions in the Seventies (London, I978), pp. 247-248.

8. ASTMS National Executive Council Minutes, MRC, 79/AS/I/4/5-I4, 8 March I 975 . Jenkins was given a right of reply in The Times when criticized for his advocacy of Soviet visits to the TUC. See MRC, Clive Jenkins papers [hereafter CJP], CJ/3/38, draft letter to editor of The Daily Mail of 26 June 1985 , re. Paterson's article of 19 June 1985 "Why Showman Jenkins Finally Got the Bird”; marked by Jenkins, "No: undignified: don't send. But file." Some of Jenkins's obituaries note his relations with the Soviet KGB; see The Daily Telegraph 25 September 1999, "Trade Unionist Whose Champagne Socialism and Success in Boosting Membership Inspired Resentment"; c.f. Terry Pattinson, The Independent 23 September 1999, Keith Harper, The Guardian 23 September 1999. 
by the ultra-left Socialist Worker, and again he proved a ruthless opponent, inflicting lethal legal costs on the left-wing New Statesman, as well as the Socialist Worker, when he was libelled. 9 These exchanges formed part of a much wider debate on the role of trade-union officers, their relationship with the membership, and the class orientation or outlook of those members. ${ }^{\text {Io }}$ The recruitment of salaried employees to white-collar unions has been an important feature of the discussion of collective bargaining and class identity for many years. ${ }^{\text {II }}$ In one important study, Bob Carter argued that the growth of ASTMS could not be adequately explained in terms of the appeal of a moderate middle-class association nor as the product of the proletarianization of the nonmanual employees. Carter suggests that the appeal of Jenkins and the growth of his union can be understood as a specific and pragmatic attempt of managers, supervisors, and others to defend their peculiar interests in a period when their needs were not likely to be fulfilled by closer alignment with either employers or manual unions. ${ }^{12}$ In explaining the left-wing causes adopted by Jenkins and the ASTMS in the period of rapid growth before 1979, Carter suggests that the rhetoric of Tribunite socialism expressed by the leadership had little impact on the great majority of members, who remained passive and uninterested in such issues. He also endorses contemporary criticisms of Jenkins as a pragmatic political opportunist who pursued connections which could serve his personal ambitions as well as those of his union. ${ }^{13}$

In discussing the growth of white-collar unionism, various authors have debated the importance of the class identity and political aspirations of

9. NEC Minutes, 8 March 1975, for the Socialist Worker court action after Paul Foot's article regarding Spanish holiday services sponsored by ASTMS and the Transport and General Workers' Union (TGWU); CJP, CJ/3/77, Richard Littlejohn of The Standard, 28 August 1986; Colin Ettinger to Jenkins, 22 September 1986, 23 October 1987, for damages of $£_{2,500}$ and an apology after Lloyd resigned from the The New Statesman for the "Onward Shuffles Norm" article of 29 August 1986; CJ/3/82, for Today, 6 June 1988, libel consideration. Interview with Richard Clements, formerly editor of TheTribune, 26 February 2002.

I0. The origins of the debate are Sidney and Beatrice Webb, Industrial Democracy (London [etc.], I902), pp. 28-33, and the portrayal of the Boilermakers' General Secretary, Robert Knight. J. McIlroy, "Still under Siege: British Trade-Unions at the Turn of the Century", HSIR, 3 (1997), pp. 93-II2, provides a survey, including a comment on an earlier debate between Zeitlin and Price.

I I. David Lockwood, The Blackcoated Worker, 2nd edn (Oxford [etc.], I989); George Bain, The Growth of White Collar Unionism (Oxford, 1970); Rosemary Crompton and Gareth Jones, White-Collar Proletariat: Deskilling and Gender in Clerical Work (London, 1984), pp. I67-i 85 and passim. Researchers such as Bain, W.J. McCarthy, and Keith and Dorothy Wedderburn also developed close links with Jenkins and ASTMS.

I2. Bob Carter, Capitalism, Class Conflict and the New Middle Class (London, 1985), pp. 200-202 and passim.

I3. Ibid., pp. 197-198; Carter draws heavily on Richter's analysis of Jenkins. See Irving Richter, Political Purpose in Trade Unions (London, 1973). 
nonmanual occupations and their organizations in shaping the development of the British labour movement. George Bain's key study of whitecollar unionism offered the celebrated statement that neither social characteristics nor workplace situation played any significant part in determining the membership of nonmanual unions. ${ }^{14}$ Exchanges have continued on the class orientation of rank-and-file unionists, though in recent years there has been greater scepticism about radical interpretations of trade-union bureaucracy and an emphasis rather on diverse institutional and personal influences in the progress of union-member relations. ${ }^{\text {Is }}$ In particular, discussions of white-collar unions have often been seen as standing some distance from the historical conflicts of manual workers and employers, even though the leaders of salaried employees have often claimed left-wing credentials. As noted above, Carter suggests that the radical rhetoric expressed by ASTMS failed to touch the passive members, whose only experience of struggle was based on the highly fragmented nature of group organization at individual plants. ${ }^{16}$ The focus of such research has often been confined to the structure of these organizations, their appeal to members, and the relationship between paid officials and the unpaid representatives of the workforce in the face of different employer strategies.

A recurring theme in discussions of the structure of trade unions and the relations between their full-time and lay officers is the capacity of the union membership to secure control over their union and to express their political ambitions in the postwar period. ${ }^{17}$ Institutionalist writers, such as Bain, have examined the specific ways in which historical experience and the recurring bargaining practice of different unions contributed to the policies pursued by such organizations, though relatively little attention has been paid to the recruitment and management of union field officers, or their contribution to the practice of trade unionism. There is little doubt that British union structures evolved in response to the bargaining environment as well as internal pressures from members and officers, as the long-term relative decline of manufacturing industry, the growing employment of women, and the sustained expansion of service occupations offered nonmanual unions fresh opportunities for recruitment.

14. Bain, Growth of White Collar Unionism, pp. I80-I 8 I and passim; cf. Carter, Capitalism, pp. $163-167,234-235$ for one critical response to Bain. For social-survey evidence which considers class perceptions of nonmanual workers, one of the most illuminating treatments remains W.G. Runciman, Relative Deprivation and Social Justice (Harmondsworth, I972), pp. I84-200 and passim.

I 5. Edmund Heery and John Kelly, "Full-time Officers and the Shop Steward Network: Patterns of Cooperation and Interdependence", in Patricia Fosh and Edmund Heery (eds), Trade Unions and their Members (Houndsmill [etc.], 1990), pp. 75-106.

16. Carter, Capitalism, pp. 195-196 for workplace groups and fragmentation.

17. Peter Fairbrother, "The Contours of Local Trade Unionism in a Period of Restructuring", in Fosh and Heery, Trade Unions, pp. I47-I I and passim. 
Jenkins and other union leaders were able to secure national agreements as they recruited in the public sector, though they also recognized the preferences of many employers for individual and company-led negotiations rather than collective negotiations via employers' organizations. ${ }^{18}$ National agreements proved elusive for nonmanual unions in the private sector, though ASTMS sought to establish industrial and company-wide bargaining by building "combines" across plants and expanding national advisory councils. Such initiatives continued after the I 968 merger with the Association of Scientific Workers and the absorption of a succession of unions and staff associations in the insurance, health, and chemicals sectors which transformed the union into a general white-collar association with an extremely diverse membership.

In publicizing the case for union membership, Jenkins highlighted the strategic contribution of scientific and technical skills to the modernization of the British economy as well as the looming threat to job security posed by the forces of technology and rationalization. ${ }^{19}$ The changing role and appeal of white-collar unions in postwar Britain was not, however, simply the consequence of the brilliant opportunism of leaders such as Jenkins, or institutional responses to the changing environment for collective bargaining. ${ }^{20}$ Before the substantial inflow of scientific, computer, and technical members after 1968, the Association led by Jenkins had little prospect of persuading employers that it represented the professional elite of British industry. ASSET had attempted to recruit executive staff during the I940s by adapting the principles of scientific management to the case for collective ownership, but attracted few managers to its ranks. As Carter noted, the movement to establish a "third force" of autonomous managers in postwar labour relations clearly failed, though ASSET had sought to align itself with the British Institute of Management as well as the TUC. ${ }^{21}$

It is rarely appreciated that the various attempts to establish "third-force bargaining" after the War were connected to an effort, by ASSET and other unions, to redefine the role of management in the British economy. Mikardo, Aplin, and other Fabians published various union pamphlets on the organization of bargaining with full employment. The same ASSET luminaries attempted to reform the union to secure effective lay manage-

I 8. Clive Jenkins, "My Strategy to I975", Industry Week, 30 January I970, pp. 8-9; Crompton and Jones, White Collar Proletariat, p. I68, Table 5.I gives total white-collar union membership as 5.I million in 1979. ASTMS claimed well over 400,000 members by 1979 .

19. ASSET Executive Policy Paper, "The Gold-Plated Handshake" (196r), and "All Systems Go?” (1962).

20. Chris Wrigley, "From ASSET to ASTMS: An Example of White-Collar Union Growth in the I960s", Historical Studies in Industrial Relations, 7 (1999), pp. 55-74.

21. Carter, Capitalism, pp. I82-186 and passim for BIM and the failure of "third-force" organization. 
ment of its officers. The fruits of such efforts were relatively paltry as membership stagnated in the late I940s. The bulk of ASSET's membership continued to be drawn from the supervisors and technicians in the skilled metalworking trades, where craft tradition remained the basis of collective discipline. Even in those grades, the manual unions remained hostile or indifferent to the rights of nonmanual workers. The Association struggled with a periodic crisis in finance and organization as it attempted to service a scattered membership, employed in small groups across the United Kingdom. Each time the executive attempted to concentrate resources on industries with the greatest potential for membership growth other sectors and regions protested at their neglect. Jenkins's solution to the conundrum of union identity was to drive recruitment by bargaining success as a platform for officer recruitment.

Whereas Carter emphasized the distance between the political rhetoric of Jenkins and the everyday concerns of his members, it is argued here that the ASTMS leadership deployed a diverse and subtle rhetoric as well as a range of political techniques to appeal to that membership. The interests of the employees whom the union sought to attract were not necessarily particular or self-evident. Rather they were identified in the process of mobilization that ASSET and ASTMS undertook. These priorities flowed from the union's historic experience of battling employers and governments, as well as other unions, in the postwar years.

The growth and complexity of its membership also presented the union with challenges for those who sought to manage its expansion. In contrast to the Associated Draughtsmen, Jenkins and his lieutenants realized the dangers of basing the union on a narrow group of occupations which could be challenged by new technology. The appeal to a wide group of salaried staff in both private and public sectors led to renewed internal debates on the appointment of specialist industrial rather than regional officers. Mergers with other unions and the absorption of staff associations were secured by granting considerable autonomy to distinct sections of members and the officers who represented them. By the I970s, ASTMS began to resemble a confederation of distinctive industrial groups and firms, recognized as sectional interests within the constitution of the union. These sequential changes in the structure and governance of the union also had an impact on the regional bodies as Jenkins and the National Executive Council (NEC) strove to manage their divisional councils and the various advisory bodies which were growing in different industries and larger firms.

These reforms in the organization of the union were driven, therefore, by a pragmatic concern to expedite the remarkable rates of growth which ASTMS secured in its early years of existence. They were also guided by the experience which its leaders and officers had accumulated in the postwar period. From its hard experiences of fighting the suspicions of the 
manual unions as well as resisting British employers, the union developed not only the means of survival but also particular ways of calculating its interests and protecting its members. To adopt the terms used by anthropologists and sociologists of institutions, unions learned to think in distinctive ways, combining a capacity to develop strategic goals and devise tactical skills, based on practical experience, with a set of values or goals which guides its political and moral vision. ${ }^{22}$ These are often attributed to rank-and-file discontents, political factionalism, struggles for leadership and status within the union, clashes of different regions, and so on. It is argued here that such factors figured in membership growth during the Jenkins era but that the capacity of officers to secure influence within the organization depended more on their ability to appeal to the main sources of authority by drawing on the precedents and practices established in the postwar years, and adapting them to build a constituency among the members. The capacity to promoting and publicizing the success of the union became a valued skill during the Jenkins years, though this was only one aspect of part of the economy of knowledge and expertise that functioned within the union. The most effective officers linked their recruitment strategies to a set of organizational preferences and policies which appealed not only to the minority of activists but also to the much larger group of members who gave tacit or open support to rival leaders and officers within the union.

There were at least three alternative approaches to organizing, recruitment, and bargaining which evolved within the union during the postwar period. They were not exclusive methods but rather organizing principles which drew on the preferences of members as well as the experience of officers. First, an industrial discipline was derived from work in the manufacturing and maintenance trades where the skilled trade background of supervisors and other members shaped the methods of bargaining. Secondly, there was an appeal to superior executive, technical, and scientific expertise, which derived from its limited representation amongst executives and senior technical personnel before the major influx of qualified staff after 1968. Thirdly, the union accrued an impressive legal and procedural expertise which originated in the struggle for government support during the I940s but was consolidated in subsequent decades. This base of knowledge enabled the union to devise effective strategies for recognition but also provoked conflict and controversy within the wider union movement. The vulnerability of ASSET in the face of hostile employers prompted the pursuit of legal and legislative remedies from the

22. Mary Douglas, How Institutions Think (London, 1987), pp. 45-46, 51; David Bloor, Wittgenstein, Rules and Institutions (London [etc.], I997), p. 32. See, for example, Taylor, The Fifth Estate, pp. 229-239 for discussion of the General and Municipal Workers' Union and its structure. 


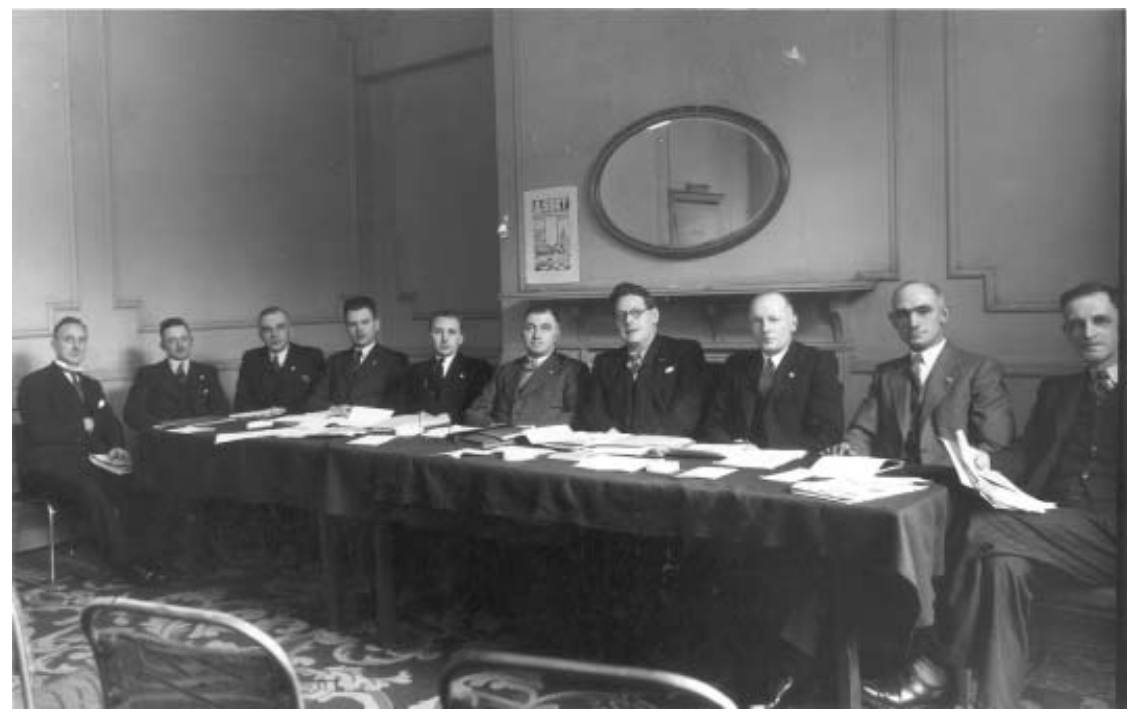

Figure I. The Old Guard: the ASSET National Executive before the radical reforms in the postwar years. Tom Agar is in the centre wearing spectacles. The later President, Jack Williams, appears to be second from the right.

Courtesy of Amicus and the Modern Record Centre, Warwick University

I940s as it sought to compel recognition for bargaining purposes, though the union had to withstand the antipathy of many manual unions to any disturbance in the delicate balance of trade-union law. ${ }^{23}$

These tensions were replicated inside the union as it grew from a tiny association of little more than 10,000 members to become the largest representative of white-collar employees in private industry, building its own workforce from the handful of officials who individually covered regions to a large squad of almost roo bargainers supported by scores of ancillary and clerical staff. ${ }^{24}$ Jenkins's personality certainly figured in the making of officer relations, though his leadership rarely extended to interference in the everyday work of the field officers or regional councils. Contrary to the impression given by his ultra-left critics, he was impatient with bureaucracy and remained an outstanding entrepreneur and publicist rather than an effective manager. ${ }^{25}$ Drawing on the distinction in forms of authority suggested by Max Weber, we could say that Jenkins continued to promote his own charismatic leadership rather than emphasizing the tradition of experience gathered in the years of deliberate struggle, or

23. Ross M. Martin, TUC: The Growth of a Pressure Group, I868-1976 (Oxford [etc.], 1980), pp. 286-288, $355 \mathrm{n} .73$ for the accommodation sought by the TUC and Jenkins's views.

24. Individual divisional officers were notionally responsible for 3,000 to 6,000 members.

25. Interview with Don Groves I 3 March 2002, Machynlleth. 
(alternatively) the importance of rational rules and predictable procedures within the organization itself. The limitations of this approach were exposed not only in adverse reactions to Jenkins's Quixotic personality.

ASSET and ASTMS officers continued to enjoy considerable autonomy from head office in the Jenkins years. The union's bargainers were expected to acquire an understanding both of particular geographical areas and a range of industries where their members were employed. Recruitment figures were the most obvious indicators of officers' success or failure, though the respect of important lay members and other officers was usually vital to advancement. Throughout this period the officers remained members of the union which employed them. Membership of the Officers' Committee could assist the rise of an individual who favourably impressed the leadership of the union and built a following among fellow officers, though there was clearly a risk of friction where the workforce enjoyed such autonomy from management directives. Even in his later years, Jenkins favoured the entrepreneurial rather than the corporate model of governance and failed to develop effective systems of control over personnel or finance. Such deficiencies became more apparent when the union faced difficult financial straits as it did in the early postwar years - and was to again after 1979.

It is argued below that political factionalism among the officers and members was of limited importance in shaping the long-term growth of the union or relations among its employees. More significant in the development of union policies and in defining the network of loyalties and contacts among the officers were the different ways of thinking about the union's purpose, style, and practice which developed over these decades. Around these distinct approaches and the personalities who advocated them were assembled officers with varying personal and political ambitions. Precedents and traditions were rooted in the historical experience of industrial bargaining, though officers also drew on values associated with a larger politics of class and organized labour. In the earlier part of this period the problems of stagnation and loss of members were accentuated but not caused by bitter political factionalism among both lay and full-time officers. This interpretation is developed in an examination of the postwar period culminating in the merger with the Association of Scientific Workers in 1968. A future article will consider the years from I968 to I979.

ORGANIZING THE GAFFER'S MEN: UNION OFFICIALS AND THE LEADERSHIP OF ASSET, I $950-$ I 968

Within weeks of assuming control of ASSET in I960 Jenkins proposed a radical overhaul of officer coverage within the union, provoking alarm amongst members of the NEC as well as sections of the 
membership. ${ }^{26}$ The Jenkins reforms were made after more than a decade of debate on the organization of the union and the management of its field officers. These discussions had been strongly coloured by the virulent factionalism within the ranks of the union during the Cold War years and by conflicts between interest groups amongst the membership. Harry Knight's predecessor, the flamboyant Tom Agar, had been forced to resign by Ian Mikardo and the NEC in 1945 following turmoil and dissensions in the handling of a key strike. Agar had transformed the union from a tiny association of foremen, mainly employed in railway workshops and engineering works, into an effective union of more than I 2,000 members by the end of the war. The union's most important breakthrough under Agar was the signing of a procedure agreement with the powerful Engineering Employers' Federation in 1944, which conceded recognition of ASSET by federated firms once the union demonstrated that it already represented a majority of members employed in any particular grade. Agar also persuaded the union conference to affiliate to the Labour Party, though, by the time this was confirmed in 1945 , the General Secretary had been overtaken by the scandal of mismanagement that led to his departure in the same year. Leadership of the union passed into the hands of Knight and two brilliant NEC members, Ian Mikardo and John Aplin. The postwar decline in membership and the continuing poverty of the union severely limited the capacity of the NEC to satisfy the annual conference and quell the frictions between the divisional councils which governed the regional members. By the close of I 950, the union anticipated an income of about $£_{25}, 000$ while expenditure exceeded $£_{28,000}$.

This was the setting for the discussion of officer coverage within the union after the 1949 Conference as ASSET's brilliant national officer, Will Rowe, presented a scheme of officer reorganization which had been prepared in consultation with his close ally on the NEC, John Aplin. Under intense pressure to recruit members and cut costs, the officers feared redundancies. Bitter personal and political rivalries had divided even the small group of ASSET officers during and after the war, though the looming crisis in the union led to the creation of an independent officers' committee by 1948 and in the financial difficulties of 1949-1950 the field staff stood together in their dealings with the NEC. ${ }^{27}$ The spirit of

26. CJP, Box CJ 24, President Keith Milner to Jenkins, 20 August I960. Jenkins became Acting General Secretary in summer 1960, though Knight's resignation was not formally announced until October. NEC Minutes, 8 October 1960.

27. NEC Minutes, I4-Is August 1948, identifies Peter Meldrum of Glasgow and Aubrey Sanders (a well-known Communist Party member in the London office), as spokesmen for the Officers' Committee. Sanders resigned in early 1949 and was replaced by Clive Jenkins, George Smith's former assistant at the Birmingham office. Officer reorganization had been discussed in early 1949 with communist Len Powell and the right-wing Smith for Officers' Committee; NEC Minutes, I2-I3 February I949. 
unity burned for only a brief moment as factional fighting erupted at Head Office and between the regional officials at the end of $1950 .{ }^{28}$ Left-wing officers, such as Len Powell, who had been recruited from the shop stewards' movement in the engineering industry, argued that the union should concentrate its resources on building industrial members in London. Right-wingers, such as the colourful George Smith in the Birmingham office, were keen to defend the principle of geographical coverage across a range of trades. ${ }^{29}$ As the NEC debated the alternative merits of industrial and regional coverage during I95I, the Officers' Committee (OC) formulated their own solution to the continuing financial difficulties of the union. They were guided by a detailed memorandum prepared by their youngest colleague, Clive Jenkins. ${ }^{30}$

The Jenkins document supported the emphasis on industrial rather than regional coverage, as well as arguing for greater autonomy for those in the field with "liberty of action for suitably sited organizing officers" who should concentrate on building members. Though still a young officer, Jenkins laid out the case for specialized, competent bargaining which could only be achieved by the union training its staff "through detailed experience. There is no better way." Permanent negotiated agreements should replace the gentlemanly exchange of letters by which many previous settlements had been secured and the union must actively publicize its wage gains as a basis not merely for future recruitment but also to realize the broader strategic and political mission of the union.

Gratitude is no substitute for understanding, in the work of creating trades unionists. They will remain members of our union if we can see they learn through contact and conflict with their employers that our union is indispensable as a supporter, adviser and organiser of their defence.

28. CJP, Box CJ 25, Irene E. Diffley to Powell, 29 November 1950 and I3 December 1950; Powell to Knight, 8 December I950; Meldrum to Powell, i4 December I950; George A Smith to Powell, I4 December 1950, and (two letters) I9 December 1950; E.J. Mans to Powell, 23 December 1950. By 1950, Powell (secretary of the Officers' Committee), Will Rowe, and Clive Jenkins were all members of the Communist Party, as were most of the clerical and administrative staff at the union's head office. Communists were well represented in the London district of the union where Powell's "London Campaign" of recruitment was directed. George Smith (supported by Seth Dewhurst from Lancashire and some other reactionary members of the NEC), was a notable opponent, who recruited E.J. Mans and the union's Finance Officer, Irene Diffley, and later Ron Dickens to his cause in I950-195 I. Interview with Jenkins, December 1998, for fraction meetings of communists.

29. Powell possibly favoured industrial and combine organization being developed by shop stewards. See NMLH, Communist Party of Great Britain archives; Papers of Industrial Organizer, Jim Matthews. CP/IND/Matthews/04/04, Memo on Industrial Organization, I 8 June 1948, noted the growth of combine committees at De Havillands and elsewhere as "a new fruitful development".

30. CJP, Box CJ 25, Officers' Memos re meeting I4 January I95 I and Memo 8 August I95 I, noting membership growth to I 3,000 by August I95 I. 


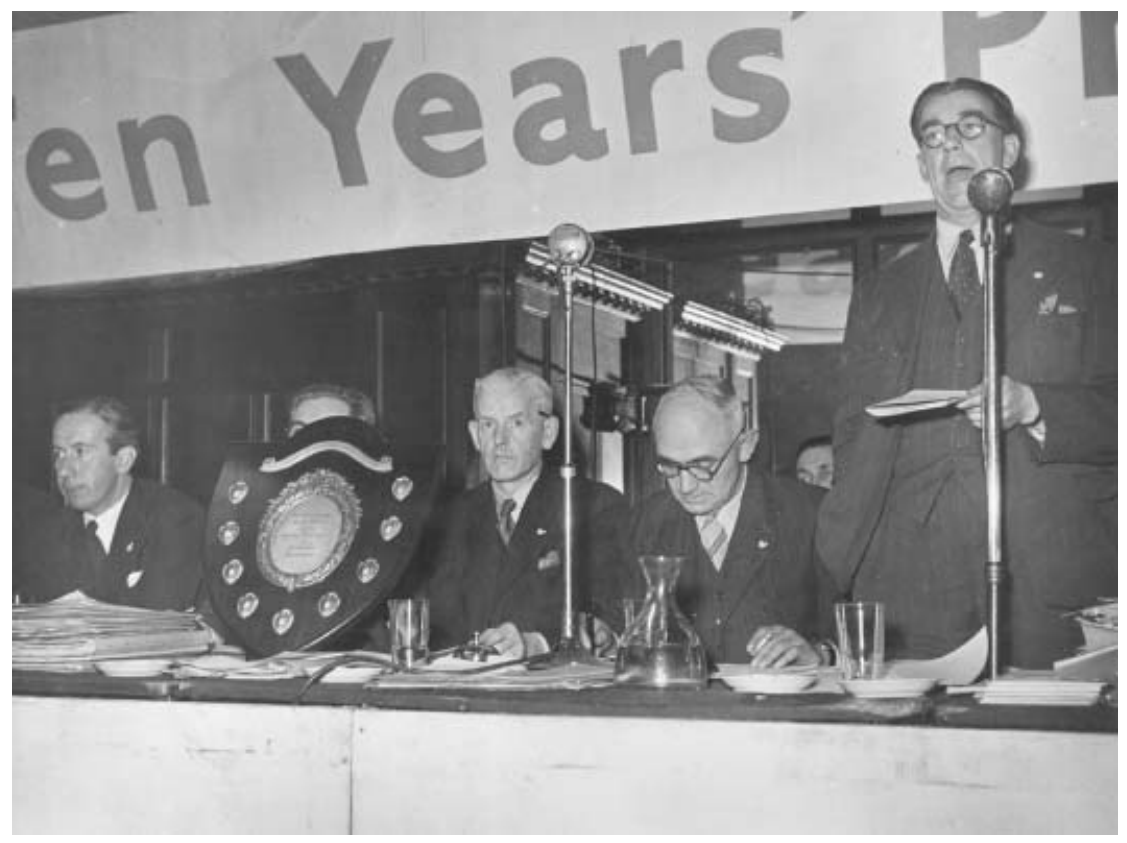

Figure 2. The ASSET leadership at the beginning of the period. Harry Knight, General Secretary of ASSET, addresses the 1948 Delegate Conference. Immediately to his right is President, Jack Williams. Next to Williams is Seth Dewhurst, the leader of the right-wing Catholic faction on the National Executive.

Courtesy of Amicus and the Modern Record Centre, Warwick University

When they have learnt this through their own experience they will stay and perhaps later embrace some of the wider ideals held in our Movement. In this way we can build the Association; consolidation will result from raising the level of understanding of our members and consciousness of their position and value as workers. ${ }^{3 \mathrm{I}}$

The Jenkins paper was only one of the contributions to the heated discussions on rationalization in $1950-195 \mathrm{I}$, but it outlined the approach to union leadership which he retained for most of his career.

His superior as general secretary, Harry Knight, claimed that reorganization had proved a success by the summer of I95 I, but it is clear that the NEC was still struggling to get a grip on the financial problems and

31. CJP, Box CJ 24, “A Personal Assessment of Reorganisation”, n.d. but appears to be document from which Jenkins's manuscript notes in regard to NEC meeting of August I95 I are summarised. See CJP Box CJ 25, Officers Memo above. The paper may date from 1954. Five industrial officers were later identified, including Jenkins as Transport Officer. 
internal feuds which beset the union. A year later, the Executive was complaining that its divisional councils in the regions spent too much time debating industrial matters and paid too little attention to vital organization. ${ }^{32}$ During the late I940s and early I950s, the union shored up its recruitment campaigns by forming "industrial councils" (sometimes with the grand title of "national councils") to coordinate activity in the major sectors of production, though its most significant council work was its participation in joint union initiatives such as the National Joint Council for Civil Air Transport. ${ }^{33}$ Membership grew only slowly from the trough of 1950 to about 16,000 by 1954 , largely as a result of the dynamic partnership of Jenkins and Ian Mikardo in the civil aviation industry. ${ }^{34}$ The gradual improvement in the financial fortunes of the union did not ease the personal frictions among senior staff and in 1954 Will Rowe resigned as Assistant General Secretary, having endured many years of bad relations with Harry Knight. This reopened the debate on the organization of officers and of head office, as criticisms of Knight's leadership mounted. 35 After vigorous internal debate, the NEC agreed to appoint an office manager rather than a senior field officer to replace the Assistant General Secretary, and also to move away from industrial coverage in favour of the traditional geographical model which had prevailed before $1949 .{ }^{36}$ Jenkins occupied a prominent position on the full-time Officers' Committee and led the protest against these changes, demanding full consultation and

32. CJP, Box CJ i I, Minutes of NEC Sub-Committee on Functions of Full-time Officers, 2 August 1952.

33. Will Rowe suggested the creation of National Industrial Councils as well as regional or "area" organizers in I 948. There were also local criticisms of the NEC's decision to send ASSET representatives to a meeting of the Joint Shop Stewards' Committee. NEC Minutes, 22-23 January 1949.

34. Mikardo had addressed a meeting of Labour MPs on the prospects for civil aviation as early as 1943 , soon after being selected as prospective Labour candidate for Reading; NMLH, Jo Richardson/Ian Mikardo papers, LP/RICH/I/I s, Ian Mikardo diary, I July I943; cutting, Reading Standard I 8 June I 943 .

35. Irene Diffley, the Finance Officer, resigned in $195 \mathrm{I}$ in a cloud of controversy, leading to press reports and an enquiry by the General Purposes and Finance Committee (GPFC). The clerical staff were represented on a Joint Consultative Committee, which negotiated grading agreements and salaries between office employees and the NEC. For staff responses to the I954 reforms see CJP, Box I I, Minutes of Joint Consultative Committee, I4 December 1954; Knight to Jessie Maurice of the Clerical and Allied Workers Union group at Head Office, 2 I December 1954: "I cannot accept that the NEC or myself for that matter, can only alter conditions within the Office after consultation and mutual agreement, irrespective of the circumstances surrounding the efficiency of Head Office, financial considerations or other matters that may arise." Also Maurice to Knight, 20 December 1954, and Knight to Maurice 4 January 1955 in regard to GPFC appeal.

36. NEC Minutes, I I-I 2 December 1954. John Lilburne was appointed as office manager while Muriel Turner continued as Knight's personal secretary. 
threatening to refuse all additional duties given them by Knight. ${ }^{37}$ The OC defended the industrial principle, arguing that specialist local knowledge was vital to success, since in many instances they could only gain ground by acting "as a guerrilla force inside or, sometimes, outside the established collective bargaining machinery". ${ }^{8}$

The renewed crisis over officer coverage in 1954-I955 divided the NEC as well as the divisional councils and the field officers which served them. Mikardo supported the scheme outlined by Knight, while John Aplin (Rowe's former mentor and a powerful London representative) supported the cause of industrial coverage. Facing a revolt of their clerical staff as well as the officers, the divided NEC refused to engage in debates on the wideranging issues raised by Jenkins and the Officers' Committee. The Executive bought off right-wing officers by agreeing to the appointment of another field officer, but Aplin resigned from the NEC in protest at the reforms and led the opposition to Knight from the conference floor. ${ }^{39}$ Aplin and Jenkins triumphed at the 1955 Annual Delegate Conference, forcing the NEC to retain industrial specialization and reconsider its coverage programme..$^{\circ}$ These struggles deepened the rifts among the field officers, as Harry Knight moved closer to the right-wingers and isolated Len Powell, the only significant communist officer who remained in a

37. ASSET General Purposes and Finance Committee, Minutes [hereafter GPFC Minutes], I4 August 1954, 28 August 1954, 4 December 1954, I5 January 1955. Jenkins's entertainment expenses were investigated by the GPFC. Len Harper was Chair and Jenkins Secretary of the Officers Committee by 1954. On Is January 1955, the Committee agreed to accept documentation but refused to recommend the suspension of the reorganization scheme. See also CJP, Box CJ 24, Knight to Jenkins 20 December 1954 re Jenkins's letter 20 December 1954 requesting status quo until consultation.

38. CJP Box II, NEC Meeting II-I2 December 1954 and minute irg4 (a), ASSET Officers' Committee, "Brief Introductory Statement", and manuscript notes of presentation, "DCJ[enkins] then led in: said he could not work new scheme. Contravened I949 decisions. Impossible burden of work"; London District Committee Minutes I 8 December 1954; ASSET GPFC Minutes, I 5 January 1955, 5 February 1955. The NEC was usually divided by nine to six on the reforms, including the rationalization of Head Office; GPFC Minutes, 5 February I955, where Jenkins argued that the new scheme "would impose impossible burdens on them"; CJP Box I I, Officers Committee to Knight, i I February 1955; Dickens and Smith to Powell, 8 February 1955, for right-wing officers' support of NEC.

39. CJP Box I , London District Committee Minutes i 8 December i954; GPFC Minutes, Is January I955, 5 February 1955; Memo of Officers' Committee to Knight, i I February I955. The NEC was itself divided on the scheme (usually by nine to six), and John Aplin resigned in protest at the reorganization; NEC Minutes I I-I2 December 1954. The NEC proposed to reorganize Head Office but not to increase the staff.

40. ASTMS Papers, MRC, 79/AS/I/2/I-4, Annual Delegate Conference Minutes, (ADC Minutes), Margate 1955. Aplin's motion was carried 6,610 to 4,710. Irene Diffley and George Smith supported Mikardo and the platform; NEC Minutes, I3-14 October 1956. A hybrid model of coverage was discussed in 1956 but little progress was made. 
senior position after Jenkins returned to the Labour Party in $1954 \cdot{ }^{4 \mathrm{I}}$ Jenkins retained close links with his former comrades in ASSET and the Electrical Trades Union (ETU), reaching an agreement with the latter on aviation membership in the face of bitter right-wing resistance within his own union. ${ }^{42}$ Jenkins was promoted to national officer in 1957 and, as the Tribunite left-wingers became dominant, Knight moved to cultivate Mikardo by joining the Victory for Socialism campaign in 1959. This brought him little credit, and when Knight's private business interests and mismanagement of union affairs antagonized Mikardo in early i 960, he was forced to resign and make way for the appointment of his brilliant assistant at the end of the year. ${ }^{43}$ On reaching office, Jenkins quickly rewarded his allies. Powell was appointed National Industrial Officer and his effective deputy, while Muriel Turner was given senior officer status as head of the administrative staff handling the union's insurance and legal business. ${ }^{44}$ When Powell retired in 1965, , Bob McCusker was brought from Scotland to serve as Assistant General Secretary. McCusker was another of Jenkins's collaborators from the aviation industry in his days as Transport Officer. ${ }^{45}$

At the start of Jenkins's tenure as General Secretary the Association remained a small, obscure union with about 25,000 members, clustered amongst a few grades of supervisory and technical employees in engineering workshops, transport (principally railways and civil aviation), and a handful of large firms, often affiliated to the Engineering Employers' Federation. Jenkins realised that the most effective and enduring solution

4I. NEC Minutes, 8-9 October 1955; Dickens and Smith complained about Powell. Also Minutes I I-I 2 February 1956.

42. NEC Minutes, 8-9 October 1955, 7-8 December 1957. The ultra-Catholic NEC member, Seth Dewhurst, resigned on the negotiation of the ETU agreement.

43. NEC Minutes, I2 December 1959, I0-I I December 1960. After criticisms by divisional councils in 1959 for his involvement a right-wing initiative for countering communist influence in Africa, Knight visited the Leipzig trade fair, antagonizing another exhibitor - Mikardo. President, Keith Milner, and right-winger, Bill Bennett, joined Mikardo in demanding that Knight forego his outside interests or resign. Knight accepted a financial settlement of $£_{2}, 500$ but faced hardship in subsequent years. He appealed to the TUC for assistance. MRC TUC Files, 292B/91/I 53, Knight to George Woodcock, Is April 1962, and 28 November 1963; Knight to Vic Feather, I7 April 1970: "I am now at the end of my financial resources. [...] Believe me, only desperation prompts me to write to you in this fashion." It is unclear if Woodcock or Feather assisted.

44. NEC Minutes, io June 1960, I0-1 i December 1960, 7/I/196I. Neither Muriel nor her fellow Assistant General Secretaries faced competitive interview, being appointed by the NEC. The anticommunists were weakened by the death of Dewhurst, and Mathison's appointment as a union official in 1960. Mathison later became a national officer (with the support of Bill Bennett), having acted as secretary of the Officers' Committee; $97 / \mathrm{AS} / 3 / 3 / 23$, Mathison to Jenkins, I 8 June 1966, for posts vacated by Powell and Turner.

45. McCusker and Jenkins had fought the closure of the Renfrew base, McCusker becoming an ASSET officer about 1956; NEC Minutes, I3-I4 October 1956. 
to the difficulties facing its hard-pressed staff lay in a significant growth of membership, and the appointment of younger officers to replace the tired and ageing colleagues who had survived from the difficult postwar years. He quickly persuaded the NEC that the priority must be effective bargaining and the creation of "district industrial officers", not unlike those whose appointment by the NEC he had challenged in 1955 , though concentrating efforts on "the big combines" of leading firms and large branches where the potential for membership growth was significant. ${ }^{46}$ During the I960s, the numbers of combines grew steadily and frequently evolved into the National Advisory Committees (NACs), with more than forty such bodies in existence by 1973, each serviced by an experienced divisional officer as secretary and chaired by an NEC member. ${ }^{47}$ The aim of the union was to use these combines to force larger firms into national bargaining, though they were more likely to secure district agreements with distinct plants or cost-centres of these enterprises. In later years the combines and NACs were serviced by employees whose salaries were paid by the companies concerned.

Jenkins lost no opportunity to point out the potential for massive growth, where half of all UK workers were employed in nonmanual occupations by 1965 , though membership of the union rose steadily rather than dramatically in his first seven years. $4^{8}$ Turnover of recruits also remained a problem, even as numbers increased to 44,000 in 1965 and the union claimed more than 50,000 paying members by the time of the merger with the AScW in 1967-1968.49 The merger proved to be the coup which transformed the fortunes of ASSET and provided the platform both for rapid growth and a succession of amalgamations in the years which followed. Before the merger became a serious prospect, even the ambitious Jenkins offered a potential target of no more than 75,000 members by I 972 , to be secured by collaboration rather than fusion with other technicians' unions. ${ }^{\circ}$ The majority of the union's members remained in the engineering trades, including those employed in civil aviation where Jenkins had made his reputation during the i950s. ${ }^{\text {II }}$ Most employers opposed recognition, while the manual unions remained suspicions of ASSET and

46. NEC Minutes, 7 January I96I, I I February 1961. Minutes 9 December 1967 for progress at AEI-GEC.

47. NEC Minutes 4-5 May i968, 9 June 1973.

48. CJP, 79/AS/6/2/1, New Society article 30 May 1963, "Gaffers' Men are Organising"; Engineering, 20 August 1965; Statist I4 January 1966. Jenkins contrasted the Amalgamated Engineering Union's disregard of the foreman as “yesterday's man”, and ASSET's positive vision for their future.

49. NEC Minutes, Io December 1966. Jenkins claimed that the 50,000 target was surpassed though he usually provided optimistic figures. It is likely that the figure was reached in 1967.

50. NEC Minutes, Io October 1965, Io December 1966.

51. 79/AS/3/3/17, File on ASSET membership. About two-thirds of members were employed in engineering. 


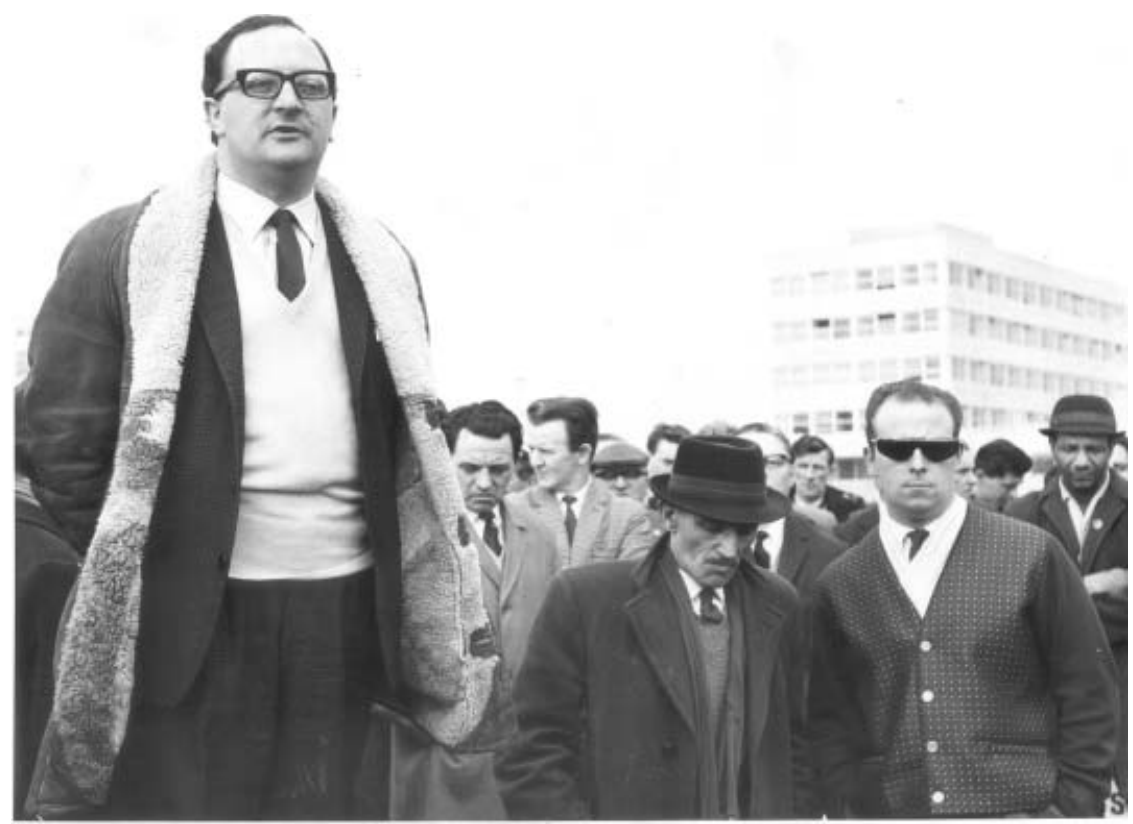

Figure 3. Addressing the workers: Clive Jenkins addresses a meeting of members in the 1950s, apparently at an airport, with two local activists in attendance.

Courtesy of Amicus and the Modern Record Centre, Warwick University

its defence of the differentials enjoyed by its supervisory and technician members. ${ }^{22}$ These constraints on the growth of ASSET explain the periodic efforts to amalgamate with other technical staff unions in this period. A merger with the Association of Scientific Workers had been discussed as early as I95 I and again in I96r. Similar initiatives were made to link up with the Association of Engineering and Shipbuilding Draughtsmen (AESD, later the Draughtsmen and Allied Technicians' Association, DATA). Subsequent merger discussions with the draughtsmen's union foundered on their commitment to industrial unionism and eventual fusion with the manual Amalgamated Engineering Union (AEU). The insistence of DATA that their merger partners should abandon nontechnician grades led to the collapse of discussions with the Association of Scientific Workers and provided Jenkins with an opportunity to

52. The EEF signed a procedure agreement in 1944 which conceded recognition where ASSET could prove a clear majority within a recognized grade of eligible employees, though the Federation also used its powerful Foremen and Staffs Mutual Benefit Society (FSMBS) as a weapon against ASSET and other staff unions. 
woo the rejected party. ${ }^{53}$ The result was the creation of the Association of Scientific, Technical, and Managerial Staffs in I 968 with Jenkins and John Dutton as joint General Secretaries.

Jenkins later claimed that he was the architect of an innovative programme of officer recruitment and training from his early days at the head of ASSET, though there is limited evidence of any systematic policy for attracting and educating field officers prior to the merger with AScW. Personal recommendation by senior figures in ASSET and other unions remained an important channel of recruitment. ${ }^{54}$ ASSET also attracted officers who had been senior lay officials in such unions as the AESD, including former communists such as Ted Mackenzie. ${ }^{5}$ A trainee scheme was introduced in 1965 , with the aim of recruiting younger people with academic or vocational qualifications who lacked experience of bargaining with employers. The scheme provided for progress to industrial and divisional officer over two years, but the impact of the probationary system was limited before the great expansion of the field workforce in the I970s. ${ }^{56}$ Nor was the training innovation of 1965 negotiated with the officers. The formal agreement between the NEC and the OC was revised in 1967 without any reference to training or any provision for the dismissal

53. NEC Minutes, I0-I I February 195 I, I June 195 I, 9 December 195 I, for AScW; 6 February I960, I0-I I December 1960. The AESD proposed that ASSET should abandon its foremen to the manual unions. Since ASSET was also firmly opposed to absorption by the AEU, little progress could be made. Jim Mortimer of DATA has been widely identified as the key advocate of industrial unionism. By this period, the AScW was financially and organizationally frail, having been bitterly assailed in the conservative press for its communist credentials. NEC Minutes, 8 May 1967, 2 July 1967; ASSET “Division I" NEC Minutes, 9 March 1968; interview with Stan Davison, 26 February 2002; interview with Jim Mortimer, 27 September 2002.

54. ASTMS 79/AS/3/9/7, correspondence of Mikardo to Jenkins: Mikardo Io August 1966, recommended Mike Redhouse (a relative of his wife, Mary), as a "good socialist and a highly political animal". Jenkins responded i 8 August 1966, that if the union kept expanding "we will always be looking for fresh talent". Redhouse was appointed as a Trainee Officer.

55. Among those senior lay officers of the AESD recruited to ASSET was Ted Mackenzie who assumed responsibility for civil aviation; NEC Minutes i M May 1962. Mackenzie was a former communist who became Vice-President and President of AESD; J.E. Mortimer, A History of the Association of Engineering and Shipbuilding Draughtsmen, (London, 1960), pp. 283-286, 436. Don Groves was recruited from the Society of Technical Civil Servants which later merged with DATA-TASS; interview with Greta Karpin, 22 April 2002.

56. Gary Morton Papers [hereafter GMP], provided by former ASTMS officer; copies in possession of author. Manuscript commentary on "questions of fact" concerning "Statement by ASTMS National Executive Council to the Chairman and Members of the Committee of the Arbitration in the case of Ms. Judy Wright (Nee Cotter)", p. 2, para. 2 (ii). The statement was presented I September 1975. The NEC claimed thirty-five trainees passed through the scheme in 1962-1975. Notes of the Officers' Committee in 1975 dated the scheme from 1965. The NEC appears to agree that the Trainee Scheme began in 1965 , following Len Powell's retirement, with the appointment of Bill Greenfield and Roger Rosewell as the first trainee probationers. As late as 1968, officers were still retaining the antiquated title of "Assistant Divisional Officer" to which Jenkins had been appointed in 1947. NEC Minutes, 24 March 1968, for request of Assistant DOs Garrard, Redhouse, and Howard to be placed on the full DO scale. 
of an officer, except by a decision of the NEC. 57 In practice, training took the form of a brief induction in the London head office and contact with senior field workers before participating in bargaining with an experienced colleague. The first batch of trainees included the brilliant but unstable Roger Rosewell who was aligned with the ultra-left, and a former draughtsman with the Atomic Energy Authority named Don Groves..$^{8}$ Not only was the training fairly rudimentary but there appeared to be only a loose system of reporting and review on the progress of trainees, leaving Jenkins with considerable personal discretion and responsibility. When Don Mathison at the Liverpool office reported that Groves was unsuitable for further training after the completion of six months probation, for example, Jenkins rejected the report and extended the trainee's probation under the more relaxed supervision of George Smith in the east Midlands. 59

The political complexion of the officers recruited remained solidly leftwing. Groves was persuaded to join the Communist Party soon after arriving at ASSET, having spent an initial training period in London where the communists had their greatest influence and support. While the employment of communist officers had been a subject of intense controversy during the Cold War, ASSET never developed the tight oligarchy of communist recruitment which was seen in the ETU after 1947, and in DATA during the I970s. ${ }^{60}$ Jenkins remained on friendly terms with a number of communists and left-wing officers who had served the Electrical Trades Union (including Mark Young), after the scandal over ballot-rigging engulfed that union. The publicity successes of Jenkins could not prevent the virulent and sustained smear campaigns which were launched against him as a former communist long after he had returned to Labour. ${ }^{61}$ There remained a clear contrast between the political profile of

57. ASTMS Papers, 79/AS/3/3/33, "Collective Bargaining Committee: Correspondence with Officers [Greta Karpin's file]"; agreement signed by Jenkins and Harry Gibbs for the OC, 22 January I $962 ; 79 / \mathrm{AS} / 3 / 3 / 23$, Memo of Mathison to Jenkins, I6 August 1966; Turner to David Phillips of W.H. Thompsons, 2 I April 1967. Mathison remained Secretary of the OC until Reg Bird assumed the role in the merged union.

58. ASTMS Staff Files, 79/AS/3/3/29. Groves was recommended by Cyril Cooper, General Secretary of the Society of Technical Civil Servants; Don Groves to Jenkins, i 8 August 1965; Greta Karpin interview, 22 April 2002.

59. ASTMS 79/AS/3/3/29, Mathison to Jenkins, 6 March I966: "he resents authority and lacks discipline"; Jenkins to Groves, Is March 1966; Smith to Jenkins I3 April 1966; Groves to Jenkins, 29 June 1966, and 19 August 1966.

60. Taylor, The Fifth Estate, pp. $225-228$ for Ken Gill and communist influence in DATA and later TASS (Technical, Administrative and Supervisory Section of AEU).

6r. NEC Minutes, i May 1959 for ASSET-ETU agreement negotiated by Jenkins; NEC Minutes, I4 October I96I, for ASSET's opposition to the expulsion of the ETU from the TUC. CJP, MRC, CJ/3/I07, "Strictly Personal \& Confidential” Report I, June I958, with Jenkins's annotation, "Who is behind this?". One of three anti-union organizations identified was financed by the US. Their activities included the sabotage of communist Joe Scott's AEU 
the Jenkins leadership and those technicians' unions dominated or influenced by communists. ${ }^{62}$ Officers recruited to ASSET in the I960s held a variety of political views, from the right wing of the Labour Party to advocates of revolutionary Marxism.

The merger with the scientific workers in 1968 brought a fresh influx of communists into the new union, as they had dominated the AScW executive and also claimed a considerable following among the officers. One of these officers was Reg Bird, who was employed in the Midlands and serviced the new ASTMS Officers' Committee. The fusion of two unions had changed the chemistry of officer relations within the union, as well as enlarging the scope for a rapid expansion of members in salaried posts. As joint General Secretary responsible for staff matters, John Dutton faced the demand from Bird, his former AScW colleague, that the trainee scheme introduced by Jenkins in the ASSET days should be abandoned and officers fully consulted before any similar arrangements were considered. ${ }^{63}$ Jenkins and the new NEC considered it politic to concede some ground to the new OC, inviting further discussion on the matter while insisting that they would "reintroduce the Training Scheme at any time it may be felt necessary". ${ }^{6}$

In 1968 Jenkins and his union stood on the threshold of a period of unprecedented growth and rapid recruitment of new officers as well as members. Jenkins subsequently claimed the credit for recognizing that spectacular growth could be secured by a succession of mergers with similar unions and staff unions across private industry and public services. The Jenkins version of trade-union history explains how his innovative advertising campaigns made a credible appeal to middle-class employees who had little or no experience of trade unionism. These gains were consolidated by the appointment and training of a new generation of officers capable of providing a professional service to sophisticated trade

election campaign; Joseph Melling, "Red Under the Collar? Clive Jenkins, White Collar Unionism and the Politics of the British Left, 1947-1965", Twentieth Century British History, I 3 (2002), pp. 4I 2-449, for a discussion.

62. Communist Party archives, NMLH, Industrial Department, "Notes on the London Industrial Shop Stewards Defence Committee", I4 September 1966 in CP/Cent/Ind/I/3. The Communist Party struggled to maintain its historical influence in the engineering trades after the dissolution of the National Shop Stewards' Council in the mid-r96os, leaving space for the growth of the ultra-leftists who provided the "rank-and-filist" analysis of trade unionism at this period.

63. ASTMS 79/AS/3/3/33, Reg Bird to John K. Dutton, I 8 March 1968. Bird called for the integration of three former ASSET trainees (Mike Garrard, Mike Redhouse, and Bob Howard) into the agreement covering divisional officers. Bird was a communist responsible for members in British Leyland Cars and Dunlop's, as well as the National Health Service; NEC Minutes, I I May 1969, for Jenkins's cautioning of Bird regarding strike calls.

64. ASTMS 79/AS/3/3/33, Jenkins and Dutton to Bird, 24 April 1968 regarding NEC Bargaining Committee at 20 April 1968. 
unionists. ${ }^{65}$ While illuminating the union's steady expansion away from its base among engineering supervisors, Jenkins's egocentric view of ASTMS's formation and growth obscures the extent to which his officers relied on shared experience, individual initiative, and political insight to sustain themselves in the field. By 1968, the union and its officers had developed a reasonably consistent approach to bargaining, based on the hard experience of dealing with employers and government rather than the public rhetoric with which Jenkins was identified.

The three alternative strands to organization were well established by the late I960s. Industrial struggles and direct action secured recognition and drew on the union's close collaboration with allies, such as the leftwing Draughtsmen's Association, as well as ASSET's own postwar experiences and contacts with engineering and electrical shop stewards. The appeal to strategic knowledge and expertise which formed the second main strand in ASSET mobilization was reflected in the rhetoric which Jenkins used so skilfully in his publicity campaigns, and which was undoubtedly amplified in Mikardo's parliamentary initiatives in periods when governments appealed for modernization and innovation. These claims to technical and scientific expertise were strengthened by the arrival of the AScW's scientific, medical, and education members, though the emphasis on defending differentials and executive salaries had already been established. The union's "forensic" approach to contractual, legal, and parliamentary issues formed the third strand in the union's accumulation of strategic knowledge and bargaining expertise during the ASSET years. The triumph over the Foremen and Staff Mutual Benefit Society by private legislation, and the unrelenting legal challenges to governments as well as employers, provided only the most visible expression of the union's formidable capacity to extend its reach beyond voluntary bargaining.

Each of these methods of building and exploiting knowledge within the union appealed to distinctive strong constituencies among the members, as well as to the officers who represented them. Jenkins and some of his colleagues would resort to each and all of these approaches when charting a route through new sectors such as civil aviation transport in the I950s, and conflicts with computer or electric equipment manufacturers in the I960s. There were also important differences of emphasis and priority among the distinct groups of members that were to become apparent in the years after the merger. The leadership of ASSET and ASTMS steadily assembled a powerful cohort of talented officers who could exploit mass communications as well as contributing to the practical, technical, and legal knowledge of the union. Strongly committed to growth and the principle of officer training, there is much less evidence that the union's

65. Clive Jenkins, All Against the Collar: Struggles of a White Collar Union Leader (London, I990), pp. I 22-I 28. 
leaders foresaw the need for a management system which would cope with the rapid expansion of income and appointments. ${ }^{66}$ For all his flamboyant claims, Jenkins failed to retain the lessons of his early career when officers were involved in bitter disputes with their employer over working conditions and consultation, arising largely from the penurious state of the union. Although the most visible dissension within the union had revolved around the employment rights of communist officers in the Cold-War years, these recriminations were fuelled by the fundamental problems of declining or stagnant membership and fragile finances.

The union's opposition to government wage controls dated back to the Labour Government's policies of I948-1949 and aroused less controversy in the union. Since ASSET was concerned to protect the pay and privileges of staff grades, wage restraints were rarely popular with members. Before and after the merger with the AScW in 1968, Mikardo and Jenkins gained publicity by their opposition to the Wilson government's pay pauses. Jenkins skilfully exploited this rhetoric, believing that an expansion of the union's membership and the recruitment of well-paid officers under his leadership would largely resolve the internal frictions which had afflicted the union for much of his early career. His memorandum of the early i950s had revealed a conviction that the union's foundations would rest on its success at the bargaining table and its capacity to translate this into success by the effective use of the mass media. The ASSET leadership developed a formidable capacity to communicate its message and to appeal to professional employees by the I960s. His primary interest in recruiting and training qualified younger people remained that of expanding the scale and fluency of his negotiating team. The next article will examine the strengths and weaknesses of his management style in the years of rapid growth after 1968 .

\section{CONCLUSIONS}

Studies of the role of trade-union officers have frequently pointed to the disparity between the democratic rhetoric employed in recruitment of members and the administrative processes which ensured that union officers became the effective rulers of the body which employed them. In the 1960s, the ultra-left in Europe and North America elaborated the criticism of moderate unionism in arguing that the nonsalaried representatives of the workforce, and political activists on the shopfloor, have often provided an important counterweight to the deadening hand of

66. Groves interview, I3 March 2002, emphasized Jenkins's failure to build an effective organization to support the growth of the union, particularly a rigorous system of training and administration. 
bureaucracy. Carter's study of Jenkins and white-collar unionism stressed the failure of the union leaders to educate their members in the politics of the wider labour movement, while retaining an abstract rhetoric of leftwing causes which had little bearing on union practice. The response from scholars using a pluralist and institutionalist model of union growth, such as Bain's influential study of white-collar unionism, has usually been to emphasize the diversity of workers' interests and the peculiar historical circumstances in which different unions built their support. In recent years, the radical case for a fundamental divide between the interests of unions officials and the lay membership has been widely dismissed.

This article has attempted a different approach to that provided in some of the key studies of white-collar unionism. It is argued here that academic research, as well as trade unions, draws on and develops contemporary rhetoric in seeking to demonstrate the contemporary relevance of their subject. Institutionalist accounts, such as Bain's, were as much a product of the political and rhetorical engagement of white-collar unions in the postwar era as were the New-Left studies which accompanied the long, uneven decline of communist influence in the workplace after 1945. Union leaders such as Jenkins were important actors in this process, rejecting the workerist agenda of the Marxist parties after 1956 (and academic commentaries) in favour of a more critical intellectual culture which drew on the practical experience of the labour movement and expressed in publications such as Trade Union Affairs. The relationship of this rhetoric to white-collar union growth was a complex and subtle one: Jenkins drew on the distinctive modes of thinking and practice which ASSET and ASTMS developed in the postwar years in developing a distinctive appeal to salaried workers. British trade unions have usually learned to think and behave in response to the success or failure of particular strategies for recruitment and bargaining rather than the political direction advocated by their leaders. Yet they have also been compelled to adapt to the legal and legislative politics of the periods in which they worked.

Over the years 1950-I968, ASSET continued to build its stock of knowledge and bargaining skills mainly through a process of learning by doing. In the early years the bargaining environment was a particularly hostile one for a union seeking to recruit managerial, technical, and scientific employees. The Association faced resistance from manual unions and competition from other staff unions, as well as the enmity of powerful employers. From the I940s, we can detect the growth of three distinctive forms of recruitment and bargaining as ASSET fought to establish its credentials with the wider union movement as well as powerful employers. The first way of working drew on the collective discipline and the craft reflexes of the metalworking trades from which ASSET recruited the core of its members, and where Powell, Rowe, and others had devised the strategy of combine organization to deal with larger firms. The second 
strand in the union's thinking and organization was the claim to professional expertise and executive authority, linked to ideas about modernization of industry and the reform of management. The third intellectual and practical resource which ASSET had assembled by the time of its merger with the AScW in I968 was a formidable legal and legislative experience, not only in the parliamentary work of Mikardo and the Parliamentary Committee but also the forensic intelligence of Turner and the union's legal department. Each of these forms of action carried their own rhetoric and logic which appealed to the membership in distinct ways.

The contribution of Jenkins was to recognize that none of the established ways of thinking about bargaining could in themselves deliver the rapid growth in membership which would secure the position of the nonmanual workforce within the British labour movement. The scope for "guerrilla" direct action was restricted to civil aviation and a few other industries at this time. Most members preferred to reach an agreement with their employers without conflict, preserving their differentials and career prospects. The different methods of bargaining were fashioned to appeal to distinctive constituencies within the union as it expanded and became less vulnerable. Legal and parliamentary initiatives gradually overcame the employers' client societies and provided a platform for challenges to government wage controls. In addition to these techniques for growth, Jenkins argued that the key to expansion lay in reaching effective bargains with employers and building a general union of nonmanual workers across industries and services. An ingenious exploitation of the mass media and advertising copy became the means by which he developed and refined the rhetoric of modernization, professionalism, and success in appealing to new recruits. His preferred model of enterprise remained the wealthy public or private corporation which could provide generous salaries and benefits for his members.

The growth of the union resolved one of the dilemmas which had blighted ASSET for much of the postwar period: namely, how to meet the competing demands for geographical and industrial coverage while achieving sufficient specialization of tasks to satisfy a diverse constituency of subscribers. Jenkins registered this problem when representing the Officers' Committee in debates on reorganization during the I950s, yet he displayed relatively little interest in the structure and administration of the union during his tenure as General Secretary. The combine committees evolved into advisory councils without any detailed guidance from the leadership of the union. Here lay an important difference between Jenkins and some of his contemporaries in the British labour movement. His reliance on charismatic leadership and realpolitik in the management of both full-time and lay officers may be contrasted with the views of intellectual collaborators such as Jim Mortimer of the Draughtsmen's 
Association. Mortimer was one of a number of white-collar leaders who advocated industrial unionism as the means by which the union movement could be realigned, and salaried staff join the manual unions in a range of strong coalitions. Jenkins believed that the historical culture of the manual unions and their enormous superiority in numbers would lead to a subordination of white-collar workers, marginalizing their influence and threatening their autonomy at the workplace. This was particularly true of supervisory and managerial grades recruited to ASSET. The failure of the proposed fusion between the Draughtsmen's Association and the AScW provided Jenkins with the great opportunity for a merger in 1967-1968.

There was also a contrast with some other left-wing leaders of whitecollar unions in Jenkins's selection and management of field officers. $\mathrm{He}$ recognized that effective bargaining and recruitment of members would depend on a corps of talented officers who could master the multiple skills of presentation and communication. In common with most other unions, ASSET had relied on the recruitment of lay activists as well as the officers of other unions to its ranks in the I940s and I950s. Unions recruited motivated individuals who shared the political values of the British labour movement. Yet Jenkins never sought to establish the kind of oligarchic control which was a feature of many other left-wing union leaderships in postwar Britain. His training scheme exploited the enthusiasm and commitment of younger people who had been educated at university or in the professions, rather than relying solely on seasoned campaigners with long experience of older industries. In practice, decisions about the selection and induction of officers remained pragmatic and personal, with recommendation and experience with other unions as important qualities. Jenkins displayed the intuitive management style which fostered a masculine competitive spirit among individual talents rather than collective discipline.

There continued to be connections between the internal mentality of union behaviour and the rhetoric of British labour politics. Officers were expected to be well versed in the ethos of the trade-union movement and were traditionally recruited from the lay officials of ASSET and its sister organizations, including the Draughtsmen's Association. The presence of communists in the ranks excited fierce controversy during the Cold-War years, as Catholic Action mobilized to exclude any CPGB member from holding office. Jenkins carried a Party card in the early i950s before returning to Labour. Even at the height of their influence, the communists claimed a minority of field officers and very few senior lay figures within the union. The left-wing followers of Bevan and Tribune were far more in evidence throughout the I950s and I960s, led by articulate Labour politicians such as Ian Mikardo. Such activists gained prominence in the Attlee years for their opposition to government wage restraint, though it is clear that Labour was itself somewhat confused in its dealings with the 
trade unions on this and other matters. ${ }^{67}$ The reactionaries within the TUC used both this and the related issue of American-led productivity drives as a weapon to isolate the communists and their supporters. In these struggles ASSET sought to link its "new managerialism" and support for legal reforms to the campaign for differential pay and improved conditions for supervisors. These initiatives yielded limited gains in recruitment and political influence before 1965 , though Jenkins was more successful in shadowing Harold Wilson's pursuit of a rhetoric of modernization in industry when building support for Labour during the I960s. It was the Wilson government's decision to reform the trade unions and control pay which set the scene for a renewed conflict with the union movement after I968, and it was in those years that Jenkins was to secure his reputation as a left-wing union leader. 